\section{Harvest Management of Marshall 'McIntosh' Apples: Effects of AVG, NAA, Ethephon, and Summer Pruning on Preharvest Drop and Fruit Quality}

\author{
Ed Stover ${ }^{1}$ and Michael J. Fargione \\ Department of Horticultural Sciences, Hudson Valley Laboratory, Cornell \\ University, P.O. Box 727, Highland, NY 12528-0727
}

\author{
Christopher B. Watkins \\ Department of Horticulture, Cornell University, Ithaca, NY 14853
}

\section{Kevin A. Iungerman \\ Cornell Cooperative Extension, Ballston Spa, NY 12020}

Additional index words. aminoethoxyvinyl glycine, 2-chloroethylphosphonic acid, controlled atmosphere storage, Ethrel, ethylene, firmness, maturity, naphthaleneacetic acid, physiological disorders, ReTain, ripening, starch

\begin{abstract}
McIntosh'apples (Malus $\times$ domestica Borkh.) display a rapid increase in ethylene production as they ripen, resulting in more preharvest drop and accelerated softening compared with other major cultivars. Economic considerations often dictate a choice between delaying harvest to achieve color development or harvesting earlier to avoid excessive fruit softening and drop. We have evaluated the effects of plant growth regulators (PGRs) and summer pruning on this balance. Treatments were applied to trees in the Mid-Hudson region in New York state in 1995 and 1996, and a subset of treatments was applied in the Champlain Valley region in 1996. NAA, applied at $10 \mathrm{mg} \cdot \mathrm{L}^{-1}$ in 1995 and $20 \mathrm{mg} \cdot \mathrm{L}^{-1}$ in 1996 , reduced drop on only one sample date in only one of the three trials. Ethephon at $150 \mathrm{mg} \cdot \mathrm{L}^{-1}$ plus $10 \mathrm{mg} \cdot \mathrm{L}^{-1} \mathrm{NAA}$, accelerated ripening and permitted harvest before substantial drop occurred. However, earlier harvest resulted in smaller fruit size, and if ethephon-treated fruit were not picked within a narrow window, rapid drop ensued, and fruit developed a high senescent breakdown incidence during storage. ReTain, containing AVG, at $124 \mathrm{~g} \cdot \mathrm{ha}^{-1}$ a.i. delayed drop in all three trials, but its use resulted in firmer fruit after storage in only two of seven comparisons. Use of ethephon on AVG-treated trees enhanced red color but accelerated drop, although it was reduced less than when ethephon was used alone. Severe late summer pruning accelerated red color development, drop and ripening in both years of the study. AVG was more effective for management of 'McIntosh' harvest in the cooler Champlain Valley region than in the Mid-Hudson Valley region. Chemical names used: naphthalene acetic acid (NAA); 2-chloroethylphosphonic acid (ethephon); aminoethoxyvinylglycine (AVG).
\end{abstract}

The 'McIntosh' apple, a major cultivar in North America and the most widely planted apple in New York, is subject to serious horticultural problems including rapid fruit ripening and frequent high losses to abscission prior to meeting U.S. Fancy Extra grade standards (Autio and Greene, 1990; Murphey and Dilley, 1988). Preharvest sprays of daminozide were previously used to slow the rate of fruit ripening and reduce preharvest drop (Edgerton and Blanpied, 1970; Elfving et al., 1991). This was particularly important in warmer areas such as

Received for publication 1 June 2001. Accepted for publication 3 Oct. 2002. This research was supported by the New York Apple Research and Development Program and AbbottLaboratories (now Valent Biosciences). We thank Richard Risio, Christiane Mulvihill, Tom Everett, and John Crockett for technical assistance.

${ }^{1}$ Current address: Univ. of Florida, Indian River Research and Education Center, 2199 South Rock Rd., Ft. Pierce, FL 34945-3138. E-mail: ewstover @ mail.ifas.ufl.edu the Hudson Valley (mid-Hudson) apple region of New York because low temperatures are necessary to stimulate anthocyanin development (Creasy, 1968).

Alternative methods to stimulate fruit color development are used by the industry. Summer pruning enhances color development by increasing light penetration to fruit (Autio and Greene, 1990; Lord and Greene, 1982; Marini and Barden, 1982, 1987; Saure, 1987). However, grower observations suggest that late summer pruning of 'McIntosh' can accelerate preharvest drop. NAA is routinely used in many orchards to reduce 'McIntosh' drop while awaiting further color development, especially following an initial picking of the most colored fruit. Some growers also use preharvest sprays of ethephon, an ethylenegenerating compound, to enhance anthocyanin development of 'McIntosh' apples permitting harvest before there is substantial preharvest drop.

ReTain, an inhibiter of ethylene production, has been registered for use on apple fruit in the United States. The active ingredient of this product is AVG, an inhibitor of 1-aminocyclopropane-1-carboxylic acid synthase (Boller et al., 1979). Preharvest sprays of AVG were shown to inhibit ethylene production by fruit, delay ripening and reduce preharvest drop in several early studies (Bangerth, 1978; Bramlage et al., 1980; Williams, 1980). The commercialization of AVG for delaying drop has created considerable interest in the apple industry (Byers, 1997; Clarke et al., 1996; Greene, 1996). However, there is relatively little published information about efficacy of ReTain, especially in relation to interactions with other management techniques and plant growth regulators, or on storage quality. Our objectives were 1) to test the efficacy of AVG on delaying fruit maturation and reducing fruit drop of the Marshall 'McIntosh' strain; 2) to investigate the effectiveness of ethephon sprays to induce color in AVG-treated fruit; 3 ) to assess fruit quality effects following application of low rates of ethephon; and 4) to assess effects of late summer pruning, with and without AVG, on fruit ripening and preharvest drop. In addition to field studies, we also stored fruit of all treatments in refrigerated air storage both years and selected treatments under controlled atmosphere (CA) conditions in 1996, where fruit from different treatments were segregated to determine treatment effects on quality after storage.

\section{Materials and Methods}

Orchard selection and management. Experiments were conducted in commercial orchards of Marshall 'McIntosh' M.9/111 planted in 1990 on silty loam soils in the Mid-Hudson (Clintondale) and Champlain (Peru) Valleys of New York. Grower-cooperators followed standard orchard practices using trickle irrigation and tree supports to a height of $2.2 \mathrm{~m}$.

Experiment design. Experiments were established using randomized complete-block design. Trees were selected to ensure negligible spray drift between treatments. Trunk cross-sectional area (TCA) and approximate fruit number per tree were determined and cropping in fruit $/ \mathrm{cm}^{2}$ TCA calculated for the mid-Hudson trees. Level of cropping was used as the blocking factor with five two-tree replications for each treatment in the mid-Hudson and five two-tree replications per treatment were used with spatial establishment of blocks in the Champlain. In each experiment, one tree in the two-tree plot was used for collection of drop data and one tree was used for fruit quality assessments.

Plant growth regulator applications. All treatments, including dates of application, are indicated in Table 1. AVG (ReTain, Valent BioSciences Corp., Libertyville, Ill.) and NAA (Fruitone-N, AmVAC Chemical Co., Newport Beach, Calif.) were applied to entire trees at $60 \%$ of the tree row volume dilute rate to minimize drip, except in one treatment in 1995, where AVG was applied by brushing $250 \mathrm{mg} \cdot \mathrm{L}^{-1} \mathrm{AVG}$ to the terminal $1 \mathrm{~cm}$ of pruning cuts immediately following 
Table 1. Description of treatments applied to Marshall 'McIntosh' M.9/MM.111.

\begin{tabular}{|c|c|c|c|}
\hline Year & Location & Treatment & Treatment description \\
\hline \multirow[t]{9}{*}{1995} & Mid-Hudson & Control & Nontreated \\
\hline & & AVG & $\begin{array}{l}\text { AVG at } 124 \mathrm{~g} \cdot \mathrm{ha}^{-1}+0.1 \% \mathrm{~L}-77 \text {, applied with timed handgun application to } \\
\text { simulate orchard speed sprayer at } 0.6 \mathrm{TRV}(8 / 16)\end{array}$ \\
\hline & & ETH & Ethephon at $150 \mathrm{mg} \cdot \mathrm{L}^{-1}+\mathrm{NAA}$ at $10 \mathrm{mg} \cdot \mathrm{L}^{-1}$, applied with handgun to runoff $(9 / 3)$ \\
\hline & & AVG/ETH & Combination of AVG and ETH described above \\
\hline & & AVG/ETHlow & AVG $(8 / 16)$ described above $+30 \mathrm{mg} \cdot \mathrm{L}^{-1}$ Ethephon applied with handgun to runoff $(8 / 27)$ \\
\hline & & PRU & Summer pruning to remove almost all current season flush $(8 / 17)$ \\
\hline & & PRU/AVG-B & Summer pruned as above, but immediately brushed $250 \mathrm{mg} \cdot \mathrm{L}^{-1}$ AVG on cuts $(8 / 17)$ \\
\hline & & NAA & NAA at $10 \mathrm{mg} \cdot \mathrm{L}^{-1}$, applied with handgun to runoff $(9 / 3)$ \\
\hline & & NAA-low4 & NAA at $2.5 \mathrm{mg} \cdot \mathrm{L}^{-1}$, applied with handgun to runoff $(8 / 15+8 / 23+8 / 31+9 / 7)$ \\
\hline \multirow[t]{12}{*}{1996} & Mid-Hudson & Control & Nontreated \\
\hline & & AVG & AVG at $124 \mathrm{~g} \cdot \mathrm{ha}^{-1}+0.1 \% \mathrm{~L}-77$, applied with orchard speed sprayer at $0.6 \mathrm{TRV}(8 / 18)$ \\
\hline & & ETH & Ethephon at $150 \mathrm{mg} \cdot \mathrm{L}^{-1}+\mathrm{NAA}$ at $10 \mathrm{mg} \cdot \mathrm{L}^{-1}$, applied with handgun to runoff $(8 / 30)$ \\
\hline & & AVG/ETH & Combination of AVG and ETH described above \\
\hline & & PRUearly & Summer pruning early to remove almost all current season flush $(8 / 1)$ \\
\hline & & PRUlate & Summer pruning late to remove almost all current season flush $(8 / 16)$ \\
\hline & & PRUearly/AVG & Combination of AVG and PRUearly described above \\
\hline & & NAA & NAA at $20 \mathrm{mg} \cdot \mathrm{L}^{-1}$, applied with orchard speed sprayer at $0.6 \mathrm{TRV}(9 / 3)$ \\
\hline & Champlain & Control & Nontreated \\
\hline & & AVG & AVG at $124 \mathrm{~g} \cdot \mathrm{ha}^{-1}+0.1 \% \mathrm{~L}-77$, applied with orchard speed sprayer at $0.6 \mathrm{TRV}(8 / 26)$ \\
\hline & & AVG-0.5 & AVG at $62 \mathrm{~g} \cdot \mathrm{ha}^{-1}+0.1 \% \mathrm{~L}-77$, applied with orchard speed sprayer at $0.6 \mathrm{TRV}(8 / 26)$ \\
\hline & & NAA & NAA at $20 \mathrm{mg} \cdot \mathrm{L}^{-1}$, applied with orchard speed sprayer at $0.6 \mathrm{TRV}(9 / 11)$ \\
\hline
\end{tabular}

summer pruning (AVG-B). In 1995, full-tree AVG and NAA applications were made using timed handgun applications to simulate an orchard speed sprayer, and in 1996 were applied using an orchard speed sprayer. AVG was always applied with $0.1 \%$ (v/v) Silwet L77 (Loveland Industries, Greeley, Col.). For full tree application, $124 \mathrm{~g} \cdot \mathrm{ha}^{-1}$ of AVG was used in each experiment, and a separate 62 $\mathrm{g} \cdot \mathrm{ha}^{-1}$ of AVG (AVG-0.5) treatment was also included in Peru in 1996. NAA was applied at $10 \mathrm{mg} \cdot \mathrm{L}^{-1}$ in 1995 and $20 \mathrm{mg} \cdot \mathrm{L}^{-1}$ in 1996 for single applications, and in 1995 NAA was also tested using four applications at $2.5 \mathrm{mg} \cdot \mathrm{L}^{-1}$ (NAA-low4) on the same trees. Ethephon (Ethrel, Rhone-Poulenc, Research Triangle, N.C.) was applied in 1995 and 1996 using a handgun to run-off at $150 \mathrm{mg} \cdot \mathrm{L}^{-1}$ and was tank-mixed with $10 \mathrm{mg} \cdot \mathrm{L}^{-1} \mathrm{NAA}(\mathrm{ETH})$; and in 1995 there was also a treatment assessing effects of a low $\left(30 \mathrm{mg} \cdot \mathrm{L}^{-1}\right)$ and earlier $(27$ Aug.) application of ethephon to trees treated with AVG (AVG/ETHlow). Several combinations of PGR treatments and combinations of pruning and PGR treatments were also.

Summer pruning. Summer pruning was only conducted at the mid-Hudson orchard. Trees were more open and smaller than most trees that would be summer-pruned commercially. Much of current season growth was removed in the vicinity of fruit. Total pruning weights were determined for each tree in each year.

The proportion of leaf surface removed by summer pruning was measured for four trees in 1996. After all fruit were dropped or harvested in 1996, trees were stripped of leaves to determine remaining leaf area. Leaf area was measured on 50-200 g weighed subsamples using an automatic area meter (Hayashi Denco Co., type AAM-5, Tokyo), and results were extrapolated to determine proportion of entire leaf area removed during summer pruning. All treatments, including dates of pruning, are indicated in Table 1.

Drop assessment. Fruit were counted and removed from under trees designated for drop assessment on a regular basis. Data collection ceased when drop approached $100 \%$ in nontreated trees, and fruit remaining on trees were counted. Data were analyzed as the cumulative percentage of total fruit that had abscised on each measurement date.

Fruit quality assessment and storage experiments. Fruit were harvested from the trees designated for fruit quality assessment on several dates. Five fruit per tree were assessed immediately after harvest for fruit weight, visual estimation of percent red color area, firmness on two peeled sides of each fruit using an Effegi penetrometer (Effegi, Alphonsine, Italy), ${ }^{\circ}$ Brix determined with a handheld refractometer (Atago Co., Tokyo), and starch hydrolysis using the Cornell Univ. generic starch chart where $1=100 \%$ starch area and $8=0 \%$ starch area (Blanpied and Silsby, 1992). Samples of fruit from each tree from the Mid-Hudson in 1995 and the Champlain in 1996 were stored at $1{ }^{\circ} \mathrm{C}$ and were removed after 8 weeks (1995) or 6 weeks (1996). At each timing, five fruits per tree were assessed for firmness and soluble solids content after 1 and $7 \mathrm{~d}$ at 16 to $22^{\circ} \mathrm{C}$.

In 1996, fruit samples from the untreated control, AVG, ethephon (ETH), AVG plus ethephon (AVG/ETH), and NAA-treated trees in the Hudson Valley orchard were used for more detailed maturity and quality analyses. On 4, 11, and 18 Sept., 90-fruit samples per tree were harvested and transported to Ithaca. On the day of harvest, color coverage (\%), internal ethylene concentrations (IEC), flesh firmness, soluble solids and starch pattern indices were determined on 10-fruit samples per replicate. IEC was measured by gas chromatography (Varian Aerograph model 3700, Walnut Creek, Calif.) using $1 \mathrm{~mL}$ of internal gas drawn into a syringe through a hypodermic needle inserted into the core cavity of each fruit. Firmness was measured on opposite sides of pared fruit using an EPT-1 pressure tester (Lake City Technical Products, Lake City, Canada) fitted with an 11.1-mm diam. tip. The combined juice expressed from both sides of the fruit during firmness measurements was collected directly onto a hand-held digital refractometer (Atago PR-100, McCormick Fruit Tech., Yakima, Wash.) and soluble solids determined. Starch hydrolysis was assessed using the Cornell Univ. generic starch chart.

Of the remaining fruit, two 40-fruit samples per replicate were placed into unstoppered 19-L glass jars and kept overnight at $2{ }^{\circ} \mathrm{C}$. Jars were then stoppered and connected to an atmosphere mixing system which delivered humidified premixed gas mixtures of $4 \mathrm{kPaO}_{2}$ and $2 \mathrm{kPaCO}_{2}$ (balance being $\mathrm{N}_{2}$ ) for 4 weeks, before $\mathrm{CO}_{2}$ partial pressures were increased to $5 \mathrm{kPa}$ following standard recommendations for storage of this 'McIntosh' strain (Watkins, 1999). Jars from each treatment were kept separate to avoid ethylene contamination between treatments. Flow rates of the gases were maintained at $200 \mathrm{~mL} / \mathrm{min}$, and the atmosphere checked at 1- to 2-d intervals by gas chromatography. Atmospheres were maintained within $0.2 \mathrm{kPa}$ of the desired partial pressures throughout the experiment.

After 3 and 6 months of storage, one jar of fruit per replicate was transferred to an evaluation room maintained at $20^{\circ} \mathrm{C}$. After 1 and $7 \mathrm{~d}$, flesh firmness and soluble solids were measured on 10 fruit as described earlier. On day 7 , the remaining fruit were rated for presence or absence of external and internal disorders.

Statistical analyses. All statistical analyses were conducted using analysis of variance (ANOVA) (Proc GLM, SAS Institute, Cary, N.C.) with means separated using Fisher's unprotected least significant difference at $P=0.05$ and $P=0.10$. Unlike Duncan's new multiple range test, this approach does not control the experiment-wise error rate but it permits the reader to easily compare means at alternative levels of significance rather than restricting interpretation to $P=0.05$. This is consistent with Marini's (1999) argument that use of $P=0.05$ is arbitrarily restrictive. Percentage data were analyzed untransformed since no transformation method resulted in 
both normally distributed error terms and homogeneous variances. Untransformed data were not found to have significantly nonhomogeneous variances using Levene's test (Proc GLM, SAS).

\section{Results}

Preharvest drop: PGR effects. AVG delayed preharvest drop relative to the controls in all studies. In the Mid-Hudson, drop of fruit from AVG-treated trees was lower than that of untreated trees after 4 Sept. (Fig. 1a) and 11 Sept. (Fig. 2a) in 1995 and 1996 respectively. In the Champlain Valley (1996), cumulative drop remained below $10 \%$ in controls through 1 Oct. when it increased above that of AVGtreated trees (Fig. 3).

NAA, at either a single application at 10 $\mathrm{mg} \cdot \mathrm{L}^{-1}$ or four applications at $2.5 \mathrm{mg} \cdot \mathrm{L}^{-1}$ (NAA-low4) did not suppress preharvest drop compared with controls in the midHudson in 1995 (Fig. 1a). However, in 1996 $20 \mathrm{mg} \cdot \mathrm{L}^{-1} \mathrm{NAA}$ (NAA) suppressed preharvest drop from 10 through 17 Sept. AVG was not more effective than NAA until 19 Sept. when cumulative drop exceeded $50 \%$ for all treatments (Fig. 2a). In the Champlain Valley, application of NAA on 11 Sept. (NAA) resulted in faster preharvest drop than in control trees from 30 Sept. through 8 Oct. (Fig. 3).

Ethephon tank-mixed with NAA (150 $\mathrm{mg} \cdot \mathrm{L}^{-1}$ Ethephon $\left.+10 \mathrm{mg} \cdot \mathrm{L}^{-1} \mathrm{NAA}\right) \mathrm{ac}-$ celerated preharvest drop compared with controls over much of the potential harvest period in 1995 and 1996 (Fig. 1b and 2a). When ethephon plus NAA was applied after AVG (AVG/ETH), preharvest drop was delayed compared with ethephon without AVG, displaying similar curves of cumulative fruit drop vs. time but lagging by 2 to 6 d over much of the drop period. A low rate of ethephon (30 $\mathrm{mg} \cdot \mathrm{L}^{-1}$ ) applied after AVG (AVG/ETHlow) in 1995 did not affect preharvest drop relative to AVG alone (Fig. 1b).

Preharvest drop: Summer pruning and AVGeffects. In 1995, total pruning wet weights of leaves removed ranged from 0.8 to $1.6 \mathrm{Kg}$, averaging $1.1 \mathrm{Kg}$, and in 1996 from 0.4 to 1.8 $\mathrm{Kg}$ with a mean of $0.8 \mathrm{Kg}$. The proportion of leaf surface removed by summer pruning in 1996 ranged from $23 \%$ to $36 \%$ with a mean of $31 \%$.

Summer pruning of trees in mid-Aug. accelerated preharvest drop compared with that of control trees in both 1995 and 1996 (Figs. 1c and 2b). AVG application to summer pruned trees (PRU/AVG-B) resulted in intermediate levels of drop which were not significantly different from controls or treatment with summer-pruning only. Summer pruning on 1 Aug. 1996 also gave an intermediate response between controls and summer pruning on 16 Aug. However, it accelerated preharvest drop relative to that of control trees when compared on 4 Sept., and delayed drop relative to pruning on 16 Aug. when cumulative drop was compared on 11 Sept.

Fruit maturity and quality. The major effects of plant growth regulators and summer pruning on fruit maturity and quality factors are provided for selected harvest dates in the Mid-Hudson for 1995 and 1996 (Tables 2, 3, and 5) and in the Champlain Valley in 1996 Table 4). Although data were collected for later harvests they are not presented because excessive fruit drop by these dates make the data difficult to interpret and of little scientific or commercial significance.

Fruit maturity and quality: Treatment effects on color. AVG treatment reduced red color of fruit vs. control fruit at two of nine comparisons (the nine comparisons result from
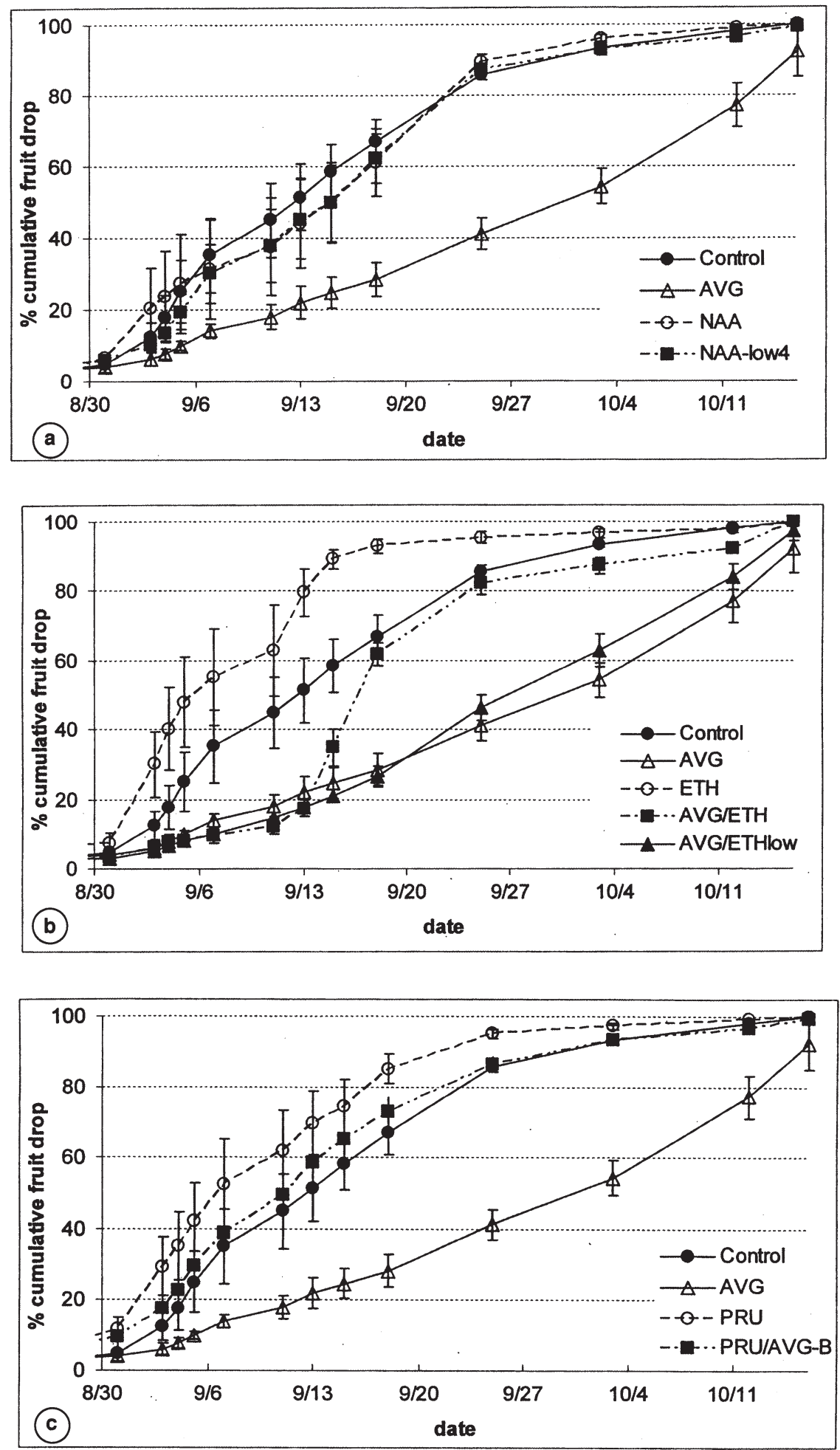

Fig. 1. Cumulative fruit drop in Marshall 'McIntosh' M.9/111 in Clintondale, N.Y. (Mid-Hudson Valley) following various treatments in 1995. In all figures, error bars represent standard errors. See Table 1 for details of treatments. a) Comparison of treatments with AVG, two NAA treatments, and control. b) Comparison of treatments with AVG, ethephon (ETH), two treatments with both AVG and ethephon, and control. c) Comparison of treatment with AVG, supper pruning (PRU), AVG application to summer pruning cuts, and control. 


\section{Crop Production}

Table 2. Maturity and quality of Marshall 'McIntosh' subjected to summer pruning and plant growth regulator treatments, Mid-Hudson, and harvested on 7, 13, and 21 Sept. 1995.

\begin{tabular}{|c|c|c|c|c|c|c|c|c|c|c|c|c|c|c|c|}
\hline \multirow[b]{2}{*}{ Treatment $^{2}$} & \multicolumn{3}{|c|}{ Red color $(\%)$} & \multicolumn{3}{|c|}{ Starch index $(0-8)$} & \multicolumn{3}{|c|}{ Soluble solids (\%) } & \multicolumn{3}{|c|}{ Firmness-harvest $(\mathrm{N})$} & \multicolumn{3}{|c|}{ Firmness-storage $^{\mathrm{y}}(\mathrm{N})$} \\
\hline & 7 Sept. & 13 Sept. & 21 Sept. & 7 Sept. & 13 Sept. & 21 Sept. & 7 Sept. & 13 Sept. & 21 Sept. & 7 Sept. & 13 Sept. & 21 Sept. & 7 Sept. & 13 Sept. & 21 Sept. \\
\hline Control & 76 & 80 & 65 & 4.8 & 5.5 & 5.8 & 12.1 & 12.5 & 9.4 & 66.8 & 67.3 & 65.7 & 42.1 & 44.0 & 43.0 \\
\hline AVG & 75 & 75 & 57 & 4.5 & 4.8 & 6.5 & 12.5 & 12.7 & 8.6 & 70.0 & 68.0 & 62.7 & 43.8 & 43.1 & 42.6 \\
\hline ETH & 84 & 91 & $\mathrm{nd}^{\mathrm{w}}$ & 5.7 & 6.0 & nd & 12.1 & 12.5 & nd & 65.4 & 64.1 & nd & 41.1 & 43.8 & nd \\
\hline AVG/ETH & 73 & 87 & 62 & 5.0 & 6.5 & 7.6 & 12.1 & 12.3 & 8.4 & 66.8 & 59.1 & 51.9 & 42.2 & 41.0 & 39.9 \\
\hline AVG/ETHlow & 74 & 82 & 58 & 5.0 & 5.4 & 6.5 & 12.1 & 12.4 & 8.5 & 69.7 & 66.4 & 62.6 & 43.9 & 42.7 & 42.3 \\
\hline PRU & 83 & 87 & 57 & 5.7 & 5.7 & 6.1 & 11.6 & 12.1 & 8.2 & 64.9 & 62.3 & 62.1 & 41.4 & 42.8 & 42.3 \\
\hline PRU/AVG-B ${ }^{x}$ & 83 & 86 & 77 & 5.2 & 5.7 & 5.9 & 11.6 & 11.9 & 10.1 & 64.3 & 63.2 & 60.5 & 42.8 & 42.5 & 42.1 \\
\hline NAA & 79 & 85 & 66 & 5.4 & 6.4 & 6.2 & 11.9 & 12.2 & 10.4 & 67.8 & 63.9 & 62.3 & 39.9 & 43.8 & 40.8 \\
\hline NAA-low4 & 79 & 85 & 68 & 5.1 & 6.1 & 5.8 & 11.8 & 12.5 & 10.3 & 67.0 & 65.4 & 63.3 & 42.6 & 44.0 & 41.2 \\
\hline \multicolumn{16}{|c|}{ Significance of ANOVA for treatment } \\
\hline & 0.004 & 0.0001 & 0.025 & 0.077 & 0.001 & 0.007 & 0.007 & 0.307 & 0.111 & 0.247 & 0.001 & 0.0001 & 0.267 & 0.091 & 0.058 \\
\hline LSD $_{0.05}$ & 6.6 & 4.5 & 19.4 & 0.80 & 0.77 & 0.95 & 0.41 & 0.62 & 0.63 & 4.88 & 4.35 & 4.48 & 3.19 & 2.04 & 2.03 \\
\hline $\mathrm{LSD}_{0.10}^{0.03}$ & 5.5 & 3.7 & 16.1 & 0.67 & 0.64 & 0.79 & 0.34 & 0.52 & 0.52 & 4.06 & 3.62 & 3.73 & 2.65 & 1.70 & 1.69 \\
\hline
\end{tabular}

${ }^{2}$ Treatments described in Table 1 .

${ }^{y}$ Evaluated after 8 weeks at $1{ }^{\circ} \mathrm{C}$ plus $1 \mathrm{~d}$ at $20^{\circ} \mathrm{C}$.

$\times 250 \mathrm{mg} \cdot \mathrm{L}^{-1}$ of AVG applied to pruning cuts immediately.

${ }^{\mathrm{w}}$ Not determined, few remaining fruit.

Table 3 Percent red color, starch indices, flesh firmness, and internal ethylene concentration (IEC), of Marshall 'McIntosh' apples, Mid-Hudson, treated with ethephon, AVG and NAA, and harvested on September 4, 6, and 11, 1996.

\begin{tabular}{|c|c|c|c|c|c|c|c|c|c|c|c|c|c|c|}
\hline \multirow[b]{2}{*}{ Treatment $^{z}$} & \multicolumn{3}{|c|}{ Red color $(\%)$} & \multicolumn{3}{|c|}{ Starch index $(0-8)$} & \multicolumn{3}{|c|}{ Soluble solids (\%) } & \multicolumn{3}{|c|}{ Firmness (N) } & \multicolumn{2}{|c|}{$\operatorname{IEC}^{y}\left(\mathrm{~mL} \cdot \mathrm{L}^{-1}\right)$} \\
\hline & 4 Sept. & 6 Sept. & 11 Sept. & 4 Sept. & 6 Sept. & 11 Sept. & 4 Sept. & 6 Sept. & 11 Sept. & 4 Sept. & 6 Sept. & 11 Sept. & 4 Sept. & 11 Sept. \\
\hline Control & 62.0 & 62.5 & 74.5 & 4.2 & 4.4 & 6.2 & 11.7 & 11.5 & 11.5 & 69.5 & 67.7 & 66.4 & 4 & 213 \\
\hline AVG & 64.3 & 64.9 & 74.5 & 4.1 & 4.6 & 6.4 & 11.5 & 11.3 & 11.6 & 69.0 & 68.5 & 68.3 & nd & 125 \\
\hline ETH & 73.7 & 83.3 & $n d^{x}$ & 5.3 & 6.5 & nd & 11.4 & 11.5 & nd & 66.0 & 63.7 & nd & 155 & 644 \\
\hline AVG/ETH & 75.5 & 84.3 & 89.0 & 4.9 & 5.9 & 7.1 & 12.1 & 12.2 & 12.1 & 67.2 & 64.1 & 57.3 & nd & nd \\
\hline PRUearly & 76.5 & 72.7 & 82.8 & 5.1 & 5.9 & 7.1 & 11.0 & 11.4 & 11.1 & 66.7 & 65.1 & 62.2 & nd & nd \\
\hline PRUlate & 72.0 & 75.2 & 82.3 & 5.0 & 5.2 & 6.4 & 11.6 & 12.1 & 11.8 & 69.2 & 67.6 & 65.5 & nd & nd \\
\hline PRUearly/AVG & 74.5 & 69.5 & 83.8 & 4.6 & 5.4 & 6.8 & 11.4 & 11.4 & 11.5 & 69.0 & 66.6 & 66.0 & nd & nd \\
\hline NAA & 66.5 & 64.0 & 82.3 & 4.2 & 4.9 & 6.7 & 11.9 & 11.8 & 11.5 & 70.2 & 68.0 & 64.7 & $\mathrm{nd}^{\mathrm{x}}$ & 217 \\
\hline \multicolumn{15}{|c|}{ Significance of ANOVA for treatment } \\
\hline & 0.002 & 0.0001 & 0.001 & 0.035 & 0.0001 & 0.0002 & 0.004 & 0.050 & 0.095 & 0.278 & 0.0001 & 0.0002 & 0.0162 & 0.0001 \\
\hline $\operatorname{LSD}_{0.05}$ & 9.26 & 6.45 & 6.67 & 0.92 & 0.88 & 0.39 & 0.52 & 0.58 & 0.66 & 3.58 & 2.41 & 4.18 & 69.6 & 93.8 \\
\hline $\mathrm{LSD}_{0.10}$ & 7.71 & 5.38 & 5.55 & 0.77 & 0.73 & 0.33 & 0.43 & 0.49 & 0.55 & 2.98 & 2.00 & 3.48 & 57.9 & 78.1 \\
\hline
\end{tabular}

Treatments described in Table 1

${ }^{y}$ Internal ethylene concentration.

${ }^{x}$ Not determined.

Table 4. Percent red color, starch indices, soluble solids, and flesh firmness of Marshall 'McIntosh' apples, Champlain, treated with NAA, or different rates of AVG, and harvested on 18 and 24 Sept. and 1 and 7 Oct., 1996.

\begin{tabular}{|c|c|c|c|c|c|c|c|c|c|c|c|c|c|c|c|}
\hline \multirow[b]{2}{*}{ Treatment $^{2}$} & \multicolumn{3}{|c|}{ Red color $(\%)$} & \multicolumn{3}{|c|}{ Starch index $(0-8)$} & \multicolumn{3}{|c|}{ Soluble solids (\%) } & \multicolumn{3}{|c|}{ Firmness-harvest (N) } & \multicolumn{3}{|c|}{ Firmness-storage $^{\mathrm{y}}(\mathrm{N})$} \\
\hline & 24 Sept. & 1 Oct. & 7 Oct. & 24 Sept. & 1 Oct. & 7 Oct. & 24 Sept. & 1 Oct. & 7 Oct. & 24 Sept. & 1 Oct. & 7 Oct. & 24 Sept. & 1 Oct. & 7 Oct. \\
\hline Control & 84.1 & 89.7 & 92.0 & 6.3 & 6.8 & 7.7 & 12.1 & 12.1 & 12.0 & 59.5 & 57.3 & 54.5 & 55.4 & 48.4 & $n d^{x}$ \\
\hline AVG & 80.7 & 86.3 & 90.0 & 5.3 & 6.1 & 7.2 & 12.9 & 12.9 & 14.5 & 62.7 & 63.7 & 64.2 & 57.5 & 53.5 & nd \\
\hline AVG-0.5 & 81.8 & 85.1 & 89.6 & 5.7 & 6.6 & 7.2 & 12.4 & 12.3 & 13.8 & 64.4 & 60.1 & 60.5 & 57.5 & 51.8 & nd \\
\hline NAA & 86.8 & 89.9 & 94.0 & 6.3 & 6.9 & 7.8 & 12.1 & 12.2 & 12.4 & 59.5 & 55.0 & 55.8 & 53.0 & 49.0 & nd \\
\hline \multicolumn{16}{|c|}{ Significance of ANOVA for teatment } \\
\hline & 0.010 & 0.006 & 0.063 & 0.105 & 0.005 & 0.009 & 0.004 & 0.032 & 0.0001 & 0.009 & 0.006 & 0.0003 & 0.007 & 0.020 & nd \\
\hline $\operatorname{LSD}_{005}$ & 3.47 & 2.85 & 3.50 & 0.94 & 0.42 & 0.40 & 0.39 & 0.52 & 0.85 & 3.15 & 4.45 & 3.69 & 2.62 & 3.36 & nd \\
\hline $\mathrm{LSD}_{0.10}^{0.05}$ & 2.84 & 2.33 & 2.86 & 0.77 & 0.34 & 0.33 & 0.32 & 0.42 & 0.70 & 2.57 & 3.64 & 3.01 & 2.15 & 2.75 & nd \\
\hline
\end{tabular}

${ }^{2}$ Treatments described in Table 1.

${ }^{y}$ Evaluated after 6 weeks at $1{ }^{\circ} \mathrm{C}$ plus $1 \mathrm{~d}$ at $20^{\circ} \mathrm{C}$.

${ }^{\mathrm{x}}$ Not determined.

three harvest dates at each of three orchard/year combinations): on the second harvest date in 1995 in the Mid-Hudson orchard (Table 2); and in the Champlain at the 1 Oct. 1996 harvest (Table 4). Red color development of fruit was enhanced by ethephon (ETH; $150 \mathrm{mg} \cdot \mathrm{L}^{-1}$, plus $10 \mathrm{mg} \cdot \mathrm{L}^{-1} \mathrm{NAA}$ ) compared with that of fruit from untreated trees at all harvests in 1995 (Table 2) and 1996 (Table 3). Pretreatment of trees with AVG, followed by the same ethephon rate and timing $(\mathrm{AVG} / \mathrm{ETH})$ slowed red color development compared with ethephon plus NAA(ETH) treatment alone in 1995, but color from these treatments was comparable by the second harvest date in 1995 and for all harvests in 1996, with both treatments producing greater color than that of control fruit. Application of ethephon at $30 \mathrm{mg} \cdot \mathrm{L}^{-1}$ increased red color of fruit previously treated with AVG (AVG/ETHlow) only at the 13 Sept. harvest (Table 2). NAA treatments resulted in greater red color than controls only on the 13 Sept. 1995 harvest in the Mid-Hudson. Summer pruning, both with and without AVG treatment, significantly advanced red color compared with controls (Tables 2 and 3 ) in five of six comparisons with the exception of the 21 Sept. 1995 harvest when drop was already excessive for these treatments.

Fruit maturity and quality: PGR effects on internal quality parameters at harvest. AVG treatments in the Mid-Hudson did not affect measured internal quality parameters compared with non-treated controls (Tables 2 and 3). The same AVG rate in the Champlain slowed starch hydrolysis, maintained fruit firmness at harvest and increased soluble solids at all three harvests, while the lower AVG rate (AVG-0.5) sometimes produced significant effects (Table 4). Ethephon (ETH) advanced starch degradation at four of five comparisons but fruit softening was not greater than the 
control until the third harvest in 1995 (Table 2) and the second harvest in 1996 (Table 3). Application of $150 \mathrm{mg} \cdot \mathrm{L}^{-1}$ ethephon to trees treated with AVG (AVG/ETH) resulted in no significant effect on starch hydrolysis or fruit softness at the first harvest but resulted in responses similar to trees treated with ethephon without AVG (ETH) at most later harvests. Application of ethephon at $30 \mathrm{mg} \cdot \mathrm{L}^{-1}$ to trees previously treated with AVG (AVG/ETHlow) had no effect on internal quality parameters compared with AVG alone. Occasional treatment effects on fruit weight were indicated in both mid-Hudson Valley and Champlain orchards, but differences were inconsistent among harvest dates, and probably reflect greater drop in larger fruit (data not shown).

Fruit maturity and quality: Summer pruning effects on internal quality parameters and interactions with $A V G$. Summer pruning resulted in greater starch hydrolysis and lower fruit firmness compared with controls at some harvest dates (Tables 2 and 3). In 1995 (Table 2), summer pruning (PRU), but not summer pruning followed by AVG application to wounds (PRU/AVG-B), resulted in higher starch indices at the 7 Sept. harvest, while pruning with and without AVG decreased fruit firmness at two of six harvest comparisons. In 1996 (Table 3), summer pruning early (1 Aug.; PRUearly), but not summer pruning late (16 Aug.; PRUlate) resulted in higher starch indices and softer fruit at all but the first harvest, and AVG application (PRUearly/AVG) had no effect on measured parameters. SS content of fruit from summer pruned-trees was lower than those from untreated trees at several harvest dates in 1995 and 1996. No effects on fruit weight were observed (data not shown)

Fruit quality after storage. After standard cold storage, most fruit from the 1995 experiment had softened substantially and few differences were detectable, except that AVG-treated fruit alone (AVG) or with low ethephon (AVG/ ETHlow) were firmer than fruit given a single NAA treatment following 7 Sept. harvest. Both AVG rates in the Champlain resulted in greater firmness out of storage when harvested on 1 Oct. 1996 but not 24 Sept. In 1996, effects of ethephon (ETH), NAA, and AVG treatment in the Mid-Hudson were assessed on fruit stored in CA for 3 and 6 months (Table 5). Since there was no interaction between treatment and storage, all data for each treatment were pooled. After storage, ethephon-treated (ETH) fruit harvested on 4 Sept. were $7.7 \mathrm{~N}$ softer across storage and shelf-life periods than the control fruit, but percentage of sound fruit (free of physiological or pathological disorders) were similar between treatments (Table 5). However, ethephon-treated fruit harvested on 11 Sept. had severe senescent breakdown (data not shown) and it was not possible to obtain accurate firmness data. AVG-treated fruit were firmer than control fruit on 11 Sept., but not 18 Sept. Other than the high incidence of breakdown in the ethephon-treated fruit on Sept. 11, the only other disorder of note was external $\mathrm{CO}_{2}$ injury. Incidence of the disorder was reduced by ethephon treatment. External $\mathrm{CO}_{2}$ injury was detected only on AVG fruit on 18 Sept.

\section{Discussion}

AVG use. ReTain (AVG) reduced preharvest fruit drop in both growing regions, but was less effective in the Mid-Hudson Valley than in the Champlain. In the Hudson Valley, a cumulative drop of $>20 \%$ of the total crop occurred in AVG treated trees by mid-Sept. in both 1995 (Fig. 1a) and 1996 (Fig. 2a). In contrast, the cooler Champlain Valley climate resulted in little early fruit drop, even in nontreated controls and showed much greater reduction in fruit drop from AVG (Fig. 3). Reasons for such regional differences in AVG effects are not completely understood. Slower fruit ethylene evolution where trees are exposed to lower temperatures during maturation may be conducive to more uniform and prolonged AVG suppression of ethylene production.

Response of 'McIntosh' to AVG in cool areas like the Champlain Valley is likely to make AVG a useful tool for commercial 'McIntosh' production. In such regions, delays of preharvest fruit drop could beneficially extend the harvest period, providing substantial cost savings by reducing the necessary number of harvest laborers. Growers in the Champlain Valley have found that savings on the high expense of U.S. entry for each harvester (through the H2A program, U.S. Dept. of Labor, 1987) will more than compensate for the cost of ReTain application in a portion of their orchard, and use of this material has become routine in this region.

Since apples typically grow by $\approx 1 \%$ per day during the few weeks before harvest (Batjer et al., 1957), use of AVG to delay harvest by 7 to $10 \mathrm{~d}$, without increasing cumulative drop, may increase production of larger high-value fruit. This may provide some benefit to use of AVG even where resulting delay in drop is more modest. Nevertheless, ReTain application to enhance 'McIntosh' crop value through increased size must be used with caution since abscission of as little as $10 \%$ of the crop may cause bruising of other fruit as the drops fall through the tree canopy.

AVG-treated Marshall 'McIntosh' fruit were firmer than control fruit at some harvests in the Champlain Valley (Tables 4), but not in the Hudson Valley (Tables 2 and 3).
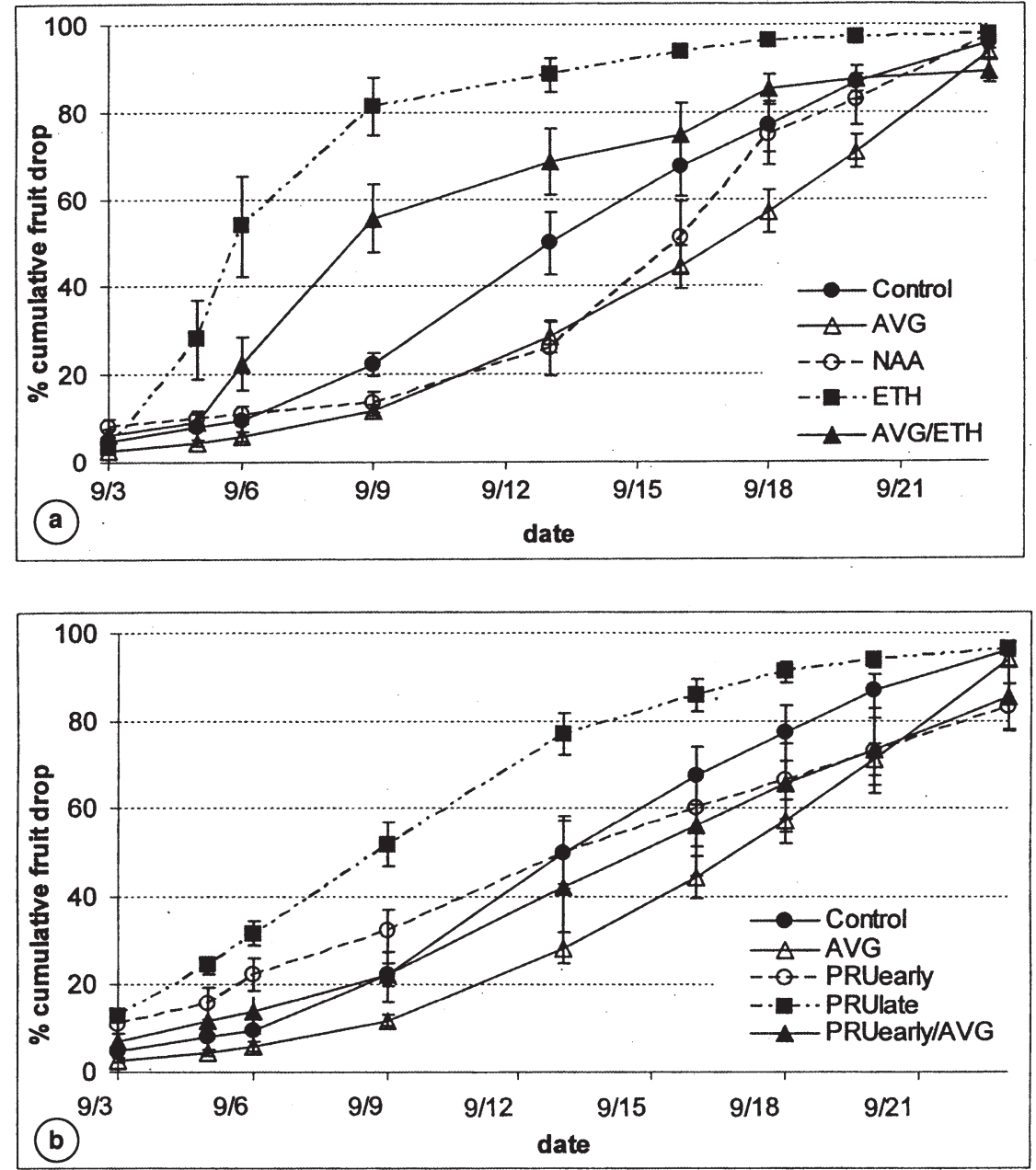

Fig. 2.Cumulative fruit drop in Marshall 'McIntosh' M.9/111 in Clintondale, N.Y. (Mid-Hudson Valley) following various PGR treatments in 1996. In all figures, error bars represent standard errors. See Table 1 for details of treatments. a) Comparison of treatments with AVG, NAA, ethephon (ETH), both AVG and ethephon, and control. b) Comparison of treatment with AVG, two times of summer pruning (PRUeaarly and PRUlate), AVG application to summer pruned trees, and control. 


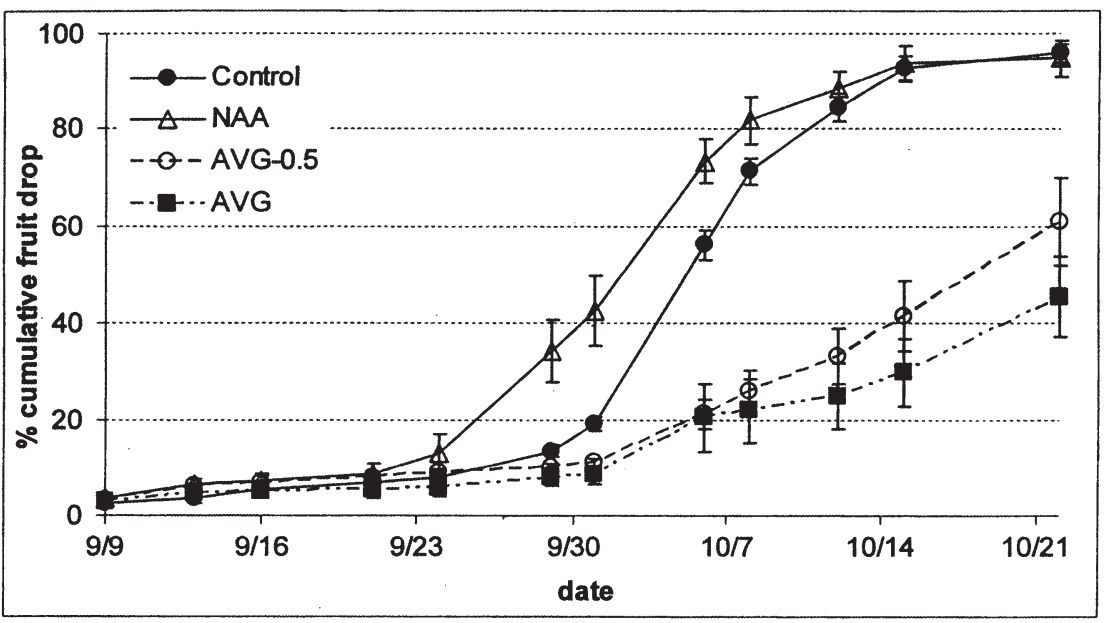

Fig. 3. Cumulative fruit drop in Marshall 'McIntosh' M.9/111 in Peru, N.Y. (Champlain Valley) following PGR treatment treatments in 1996. Error bars represent standard errors. See Table 1 for details of treatments. drop occurs. However, the potential value of
The economic advantages of improved fruit firmness following AVG-treatment, when it occurs, are not easy to quantify.

$N A A$ use. Irregular response to NAA in these experiments is consistent with the experience that NAA is an effective stop drop material for 'McIntosh' about $50 \%$ to $65 \%$ of the time (Duane Greene, personal communication). NAA appears to be unsuitable as a planned element of 'McIntosh' harvest management (Table 5). However, because of its modest cost and rapid action, NAA remains a useful emergency treatment.

Ethephon use on AVG-treated fruit. Slower color development was observed in AVGtreated fruit in two of the three experiments (Tables 2 and 4). Application of ethephon to AVG treated trees (AVG/ETH) largely reversed this effect (Tables 2 and 3 ). Any poststorage benefits of AVG are likely to be lost when combined with ethephon treatment.

Ethephon use for early harvest. 'McIntosh' is one of the earliest cultivars with high market demand each fall, but adequate color development is frequently a problem. The high levels of early drop seen in 1995 demonstrate the potential dangers of using ethephon to en-

hance color and harvest fruit before preharvest ethephon treatment is apparent when comparing data on ethephon treated fruit (ETH) harvested on 4 Sept. 1996 with control fruit harvested on 11 Sept. 1996: red color and firmness at harvest were almost identical (Table 3 ), but the control fruit had $35 \%$ cumulative drop by 11 Sept. vs. $6 \%$ cumulative drop for ethephon-treated fruit on 4 Sept. (Fig. 2A). When properly handled, it does appear from these data that ethephon treatment can be used to obtain early red color and minimal drop, and that quality, while reduced, may be commercially acceptable after storage.

Summer pruning. Summer pruning enhanced fruit color development compared with nontreated controls, but the aggressive summer pruning used in these studies also accelerated preharvest fruit drop and starch hydrolysis compared with the untreated controls. It must be emphasized that the degree of summer pruning used in this study exceeds most commercial practice and should be interpreted accordingly. Use of AVG on summer pruned trees sometimes reversed some but not all of the deleterious effects of summer pruning. These

Table 5. Flesh firmness, percent sound fruit, and incidence of external $\mathrm{CO}_{2}$ injury of Marshall 'McIntosh' apples, mid-Hudson, treated with ethephon, AVG and NAA, harvested on 4, 11 and 18 Sept., 1996, and stored in CA-storage for 3 and 6 months. Fruit were evaluated after 1 and $7 \mathrm{~d}$ at $20^{\circ} \mathrm{C}$ following removal from CA. No interactions were significant between treatment and storage period or time removed from storage and therefore data presented are means for all storage periods and days at $20^{\circ} \mathrm{C}$.

\begin{tabular}{|c|c|c|c|c|c|c|c|c|c|}
\hline \multirow[b]{2}{*}{ Treatment $^{2}$} & \multicolumn{3}{|c|}{ Firmness (N) } & \multicolumn{3}{|c|}{ Sound fruit (\%) } & \multicolumn{3}{|c|}{ External $\mathrm{CO}_{2}$ injury (\%) } \\
\hline & 4 Sept. & 11 Sept. & 18 Sept. & $4 \mathrm{Sept}$ & $11 \mathrm{Sept}$ & 18 Sept. & 4 Sept. & 11 Sept. & 18 Sept. \\
\hline Control & 55.3 & 50.3 & 45.6 & 76 & 89 & 97 & 16 & 10 & 0 \\
\hline AVG & nd & 54.0 & 46.2 & nd & 87 & 95 & nd & 9 & 3 \\
\hline ETH & 47.6 & $\mathrm{nd}^{y}$ & nd & 82 & 28 & nd & 12 & 1 & nd \\
\hline AVG/ETH & nd & 51.9 & 43.7 & nd & 83 & 95 & nd & 11 & 0 \\
\hline NAA & nd & 51.3 & 44.7 & nd & 70 & 83 & nd & 10 & 0 \\
\hline Significance of ANOVA & & & & & & & & & \\
\hline for treatment & **** & $*$ & $* *$ & $\mathrm{NS}^{\mathrm{w}}$ & $* * *$ & $* * *$ & NS & $* *$ & $* *$ \\
\hline LSD $_{0.05}$ & 1.07 & 1.65 & 0.70 & NS & 7.6 & 1.4 & NS & 1.6 & 0.9 \\
\hline $\operatorname{LSD}_{0,10}$ & 0.89 & 1.37 & 0.58 & NS & 6.3 & 1.2 & NS & 1.3 & 0.7 \\
\hline
\end{tabular}

${ }^{2}$ Treatments described in Table 1.

${ }^{y}$ Not determined.

wo significant differences found at $P=0.05$.

ns, *,******Nonsignificant or significant at $P<0.05,0.01$ or 0.001 , respectively. results suggest that 'McIntosh' growers may need to anticipate earlier fruit drop when trees have been heavily summer pruned.

\section{Literature Cited}

Autio W.R. and D.W. Greene. 1990. Summer pruning affects yield and improves fruit quality of 'McIntosh' apples. J. Amer. Soc. Hort. Sci. 115:356-359.

Bangerth, F. 1978. The effect of a substituted amino acid on ethylene biosynthesis, respiration, ripening and preharvest drop of apple fruits. J. Amer. Soc. Hort. Sci. 116:195-200.

Batjer, L. P., H. D. Billingsley, M. N. Westwood, and B. L. Rogers. 1957. Predicting harvest size of apples at different times during the growing season. Proc. Amer. Soc. Hort. Sci. 70:46-67.

Boller, T., R.C. Herner, and H. Kende. 1979. Assay for and enzymatic formation of an ethylene precursor, 1-aminocyclopropane-1-carboxylic acid. Planta 145:293-303.

Bramlage, W.J., D.W. Greene, W.R. Autio, and J.M. McLaughlin. 1980. Effects of aminoethoxyvinylglycine on internal ethylene concentrations and storage of apples. J. Amer. Soc. Hort. Sci. 105:847-851.

Blanpied, G.D. and K.J. Silsby. 1992. Predicting harvest date windows for apples. Info. Bul. 221, Cornell Coop. Ext.

Byers, R.E. 1997. Effects of aminoethoxyvinylglycine (AVG) on preharvest fruit drop, maturity, and cracking of several apple cultivars. J. Tree Fruit Prod. 2:77-97.

Chu, C.L. 1988. Internal ethylene concentration of 'McIntosh', 'Northern Spy', 'Empire', 'Mutsu', and 'Idared' apples during the harvest season. J. Amer. Soc. Hort. Sci. 113:226-229.

Clarke, G.G., W.E. Shafer, and B.N. Devisetty. 1996. ABG-3168: a new, naturally-occurring plant growth regulator for the apple industry. New England Fruit Meetings 102:85-89.

Creasy, L.L. 1968. The role of low temperature in anthocyanin synthesis in 'McIntosh' apples. Proc. Amer. Soc. Hort. Sci. 93:716-724.

Edgerton, L.J. and G.D. Blanpied. 1970. Interaction of succinic acid 2,2-dimethyl hydrazide, 2-chloroethylphosphonic acid and auxins on maturity, quality and abscission of apples. J. Amer. Soc. Hort. Sci. 95:664-666.

Elfving,D.C., E.C. Lougheed, and R.A. Cline. 1991. Daminozide, root pruning, trunk scoring, and trunk ringing effects on fruit ripening and storage behavior of 'McIntosh' apple. J. Amer. Soc. Hort. Sci. 116:195-200.

Greene, D., K. Kaminsky, and J. Sincuk. 1987. An evaluation of drop materials in 1986. Proc. Mass Fruit Growers' Assoc. 93:74-78.

Greene, D.W. 1996. AVG: A new preharvest drop compound for apples. New England Fruit Meetings 102:79-84.

Greene, D.W., W.J. Lord, F.W. Southwick, and W.J. Bramlage. 1973. Effects of SADH (Alar), ethephon and preharvest drop control chemicals on quality of McIntosh apples.

Larrigaudiere, C., E. Pinto, and M. Vendrell. 1996. Differential effects of ethephon and seniphos on color development of 'Starking Delicious' apple. J. Amer. Soc. Hort. Sci. 121:746-750.

Lord, W.J. and D.W. Greene. 1982. Effects of summer pruning on the quality of 'McIntosh' apples. HortScience 17:372v373.

Marini, R.P. 1999. Are nonsignificant differences really not significant? HortScience 34:761-762.

Marini, R.P. and J.A. Barden. 1982. Yield, fruit size, and quality of three apple cultivars as influenced by summer or dormant pruning. J. Amer. Soc. Hort. Sci. 107:474-479. 
Marini, R.P. and J.A. Barden. 1987. Summer pruning of apple and peach trees. Hort Rev. 9:351-375.

Murphey, A. S. and D.R. Dilley. 1988. Anthocyanin biosynthesis and maturity of 'McIntosh' apples as influenced by ethylene-releasing compounds. J. Amer. Soc. Hort. Sci. 113:718-723.

Myers, S.C. and D.C. Ferree. 1983. Influence of time of summer pruning and limb orientation on yield, fruit size, and quality of vigorous 'Delicious' apple trees. J. Amer. Soc. Hort. Sci. 108:630-633.

Saure, M.C. 1987. Summer pruning effects in apple-A review. Scientia Hort. 30:253-282.

Schupp, J.R. 1992. Effects of root pruning and summer pruning on growth, yield, quality, and fruit maturity of McIntosh apple trees. Acta Hort. 322:173-175.

Smock, R.M. and G.D. Blanpied. 1972. Controlled atmosphere storage of apples. Info. Bul. 41, Cornell Univ., Ithaca, N.Y.

Stover, E., C. Watkins, and K. Iungerman. 1999. ReTain (AVG) effects on 'McIntosh'. New York Fruit Quarterly 7(3):15-17.

Taylor, B.H. and D.C. Ferree. 1984. The influence of summer pruning and cropping on growth and fruiting of apple. J. Amer. Soc. Hort. Sci. 109:19-24.

U.S. Department of Labor. 1987. Labor certification process for temporary agricultural employment in the United States (H-2A Workers). CFR Title 20 Chapter V Part 655-B

Watkins, C.B. 1999. New York recommendations for controlled atmosphere storage and application of diphenylamine. p 24-34. CA Storage: Meeting the market Requirements, Natural Resource, Agriculture, and Engineering Service-136.

Watkins, C.B., K.J. Silsby, and M.C. Goffinet. 1997. Controlled atmosphere and antioxidant effects on external $\mathrm{CO}_{2}$ injury of 'Empire' apples. HortScience 32:1242-1246.

Williams, M.W. 1980. Retention of fruit firmness and increase in vegetative growth and fruit set of apples with aminoethoxyvinylglycine. HortScience 15:76-77. 